Article

\title{
Oxysterols from a Marine Sponge Inflatella sp. and Their Action in 6-Hydroxydopamine-Induced Cell Model of Parkinson's Disease
}

\author{
Sophia A. Kolesnikova ${ }^{1, *,+}$, Ekaterina G. Lyakhova ${ }^{1,+}{ }^{,}$, Anatoly I. Kalinovsky ${ }^{1}$, \\ Roman S. Popov ${ }^{1}$, Ekaterina A. Yurchenko ${ }^{1}$ and Valentin A. Stonik ${ }^{1,2}$ \\ 1 G.B. Elyakov Pacific Institute of Bioorganic Chemistry (PIBOC), Prospect 100-let Vladivostoku 159, \\ Vladivostok 690022, Russia; elyakhova@inbox.ru (E.G.L.); kaaniv@piboc.dvo.ru (A.I.K.); \\ prs_90@mail.ru (R.S.P.); dminae@mail.ru (E.A.Y.); office@piboc.dvo.ru or schoolNS@dvfu.ru or \\ stonik@piboc.dvo.ru (V.A.S.) \\ 2 School of Natural Science, Far Eastern Federal University, Sukhanova St., 8, Vladivostok 690000, Russia \\ * Correspondence: sovin81@inbox.ru; Tel.: +7-423-231-1168 \\ $\dagger$ These authors contributed equally to the work.
}

Received: 25 October 2018; Accepted: 19 November 2018; Published: 21 November 2018

\begin{abstract}
Four new oxysterols 1-4 along with previously known oxygenated sterols 5-14 were isolated from the sponge Inflatella sp., collected from the Sea of Okhotsk. Structures of 1-4 were elucidated by the detailed NMR spectroscopic and mass-spectrometric analyses as well as by comparison of the corresponding experimental data with those reported in literature. The influence of compounds 1-14 on the viability of neuronal Neuro2a cells treated by 6-hydroxydopamine and reactive oxygen species (ROS) formation in these cells was investigated.
\end{abstract}

Keywords: secondary metabolites; oxygenated steroids; marine sponge; Inflatella; NMR; ROS; Parkinson's disease; structure-activity relationship

\section{Introduction}

Oxysterols, formed either enzymatically or by auto-oxidation, have a second oxygen function in addition to that of C-3 when compared with natural sterols. These compounds are of particular interest due to important biological functions of some of them and various bioactivities, including effects on lipid metabolism, platelet aggregation, apoptosis, different receptors and proteins [1]. Generally, oxysterols attract a great attention by the contribution to many physiological processes, including those connected with pathophysiology of the neurodegenerative diseases [2]. As a key trend, the roles of two brain sterols, 24S-hydroxycholesterol and 27-hydroxycholesterol, have been studied for years and discussed in multiple reports [3-5]. Among others, 24S-hydroxycholesterol has been reported to be markedly reduced in the circulation of patients with Parkinson's disease (PD) [4]. The treatment with 27-hydroxycholesterol or a combination of 24S-hydroxycholesterol and 27-hydroxycholesterol reduced the levels of noradrenaline, whereas the treatment with 24S-hydroxycholesterol alone had no effect. With these results, the authors demonstrated that oxysterols could regulate the proteins involved in the development of PD [5].

Recently, some other oxysterols were found to be exported from the brain: $7 \beta$-hydroxycholesterol, 7-ketocholesterol, $3 \beta, 5 \alpha$-dihydroxycholestan-6-one, $\quad 7 \alpha$-hydroxy-3-oxocholest-4-enoic acid, $7 \alpha, 25$-dihydroxycholest-4-en-3-one, and (25R)-7 $\alpha, 26$-dihydroxycholest-4-en-3-one. It was underlined that these transfers were observed when total oxysterols were measured $[6,7]$. These facts give a new quest to disclose possible roles and bioactivities of non-common oxysterols, including those of marine origin, in development of PD and other neurodegenerative diseases. 
Recent studies highlighted the point that even well-known oxygenated sterols might be a critical source of new medicine leads. Thus, hecogenin and cholest-4-en-3-one showed significant inhibitory activity ( $\mathrm{EC}_{50}$ values of 116.3 and $390.6 \mu \mathrm{M}$, respectively) against the human $\beta$-site amyloid cleaving enzyme (BACE1), which has been considered as an effective drug target for treatment of Alzheimer's disease [8].

The search for new oxysterols in marine organisms and the studies on their action in model cell systems could be also considered as an approach to the creation of new pharmaceutical leads against neurodegenerative diseases. As a part of our chemical investigations of steroidal compounds from marine sponges [9-11], we have studied oxysterols of a cold-water marine sponge Inflatella sp. The sponges belonging to the genus Inflatella are insufficiently studied for their secondary metabolites, though some bioactivities of their extracts were noted [12]. The ethanol extract of the studied Inflatella sp. sample was preliminary analyzed by thin-layer chromatography during the screening of sponge samples from PIBOC collection. The results revealed that in contrast with extracts of other sponges, it contained the oxygenated steroids visually detected on chromatograms as a number of bright colored spots (Figure S1). Herein we describe the isolation and structural elucidation of fourteen individual oxysterols of Inflatella sp., including four new compounds as well as the results of their biotesting using a cell model of PD. Part of this work has been presented at the 3rd International Symposium on Life Sciences, Vladivostok, Russia, September 2018.

\section{Results and Discussion}

The ethanol extract of a sponge Inflatella sp., collected in the Sea of Okhotsk, was concentrated and partitioned between distilled water and $\mathrm{CHCl}_{3}$. The obtained organic layer was further separated using a combination of column chromatography and normal- or reverse-phase HPLC to yield compounds 1-14 (Figure 1). To identify the structures of isolated compounds, along with the absolute stereochemistry, their NMR and HRESI MS characteristics were analyzed and compared with previously published data [13-18].
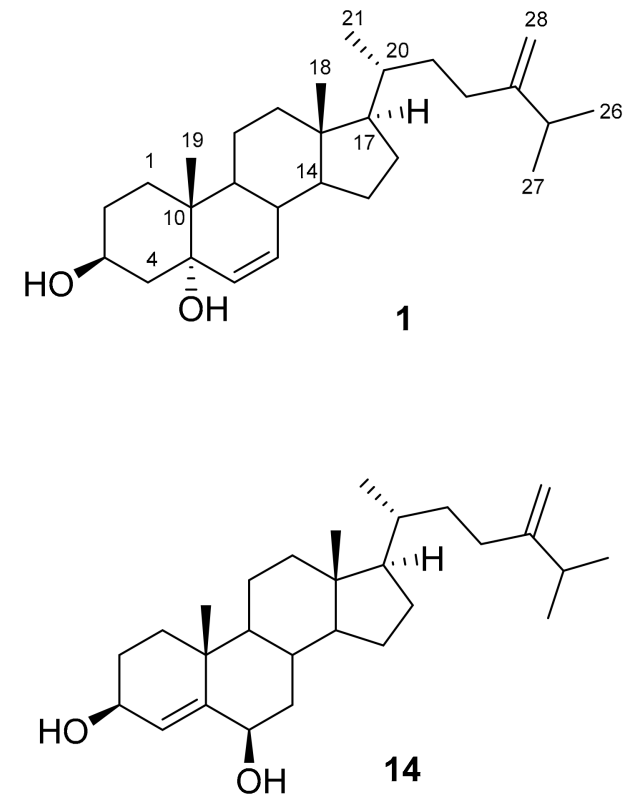

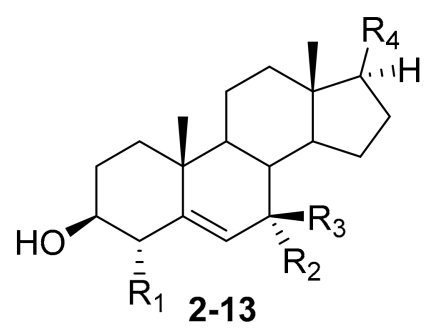

$2 \mathrm{R}_{1}=\mathrm{OH} ; \mathrm{R}_{2}=\mathrm{H} ; \mathrm{R}_{3}=\mathrm{H} ; \mathrm{R}_{4}=\mathrm{a}$

$3 \quad \mathbf{R}_{1}=\mathrm{H} ; \mathrm{R}_{2}=\mathrm{OH} ; \mathrm{R}_{3}=\mathrm{H} ; \mathbf{R}_{4}=\mathrm{b}$

$4 \quad \mathbf{R}_{1}=\mathrm{H} ; \mathbf{R}_{2}=\mathrm{H} ; \mathbf{R}_{3}=\mathrm{OH} ; \mathbf{R}_{\mathbf{4}}=\mathrm{b}$

$5 \quad R_{1}=H ; R_{2}=O H ; R_{3}=H ; R_{4}=c$

$6 \quad R_{1}=H ; R_{2}=H ; R_{3}=O H ; R_{4}=c$

$7 \quad \mathrm{R}_{1}=\mathrm{H} ; \mathrm{R}_{2}=\mathrm{OH} ; \mathrm{R}_{3}=\mathrm{H} ; \mathrm{R}_{4}=\mathrm{a}$

$8 \quad \mathbf{R}_{\mathbf{1}}=\mathrm{H} ; \mathbf{R}_{\mathbf{2}}=\mathrm{H} ; \mathbf{R}_{3}=\mathrm{OH} ; \mathbf{R}_{\mathbf{4}}=\mathrm{a}$

$9 \quad \mathrm{R}_{1}=\mathrm{H} ; \mathrm{R}_{2}=\mathrm{OH} ; \mathrm{R}_{3}=\mathrm{H} ; \mathrm{R}_{4}=\mathrm{d}$

$10 \mathrm{R}_{1}=\mathrm{H} ; \mathrm{R}_{2}=\mathrm{H} ; \mathrm{R}_{3}=\mathrm{OH} ; \mathrm{R}_{4}=\mathrm{d}$

$11 \mathrm{R}_{1}=\mathrm{H} ; \mathrm{R}_{2}=\mathrm{OH} ; \mathrm{R}_{3}=\mathrm{H} ; \mathrm{R}_{4}=\mathrm{e}$

$12 \mathrm{R}_{1}=\mathrm{H} ; \mathrm{R}_{2}=\mathrm{H} ; \mathrm{R}_{3}=\mathrm{OH} ; \mathrm{R}_{4}=\mathrm{f}$

$13 R_{1}=H ; R_{2}, R_{3}=0 ; R_{4}=a$
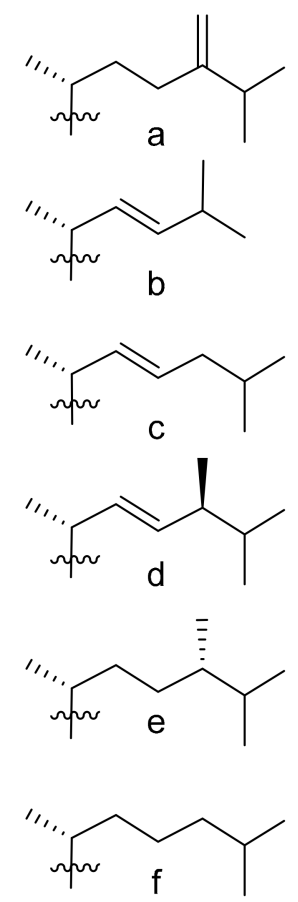

Figure 1. Structures of compounds 1-14.

Compound 1 was isolated as white amorphous powder with molecular formula $\mathrm{C}_{28} \mathrm{H}_{46} \mathrm{O}_{2}$, established from (+) HRESI MS $\left(\mathrm{m} / z 437.3393[\mathrm{M}+\mathrm{Na}]^{+}\right)$and ${ }^{13} \mathrm{C}$ NMR spectroscopic data (Figures S2 
and S4; Table 1). The ${ }^{1} \mathrm{H}$ and ${ }^{13} \mathrm{C}$ NMR spectra (Tables 1 and 2; Figures $\mathrm{S} 3$ and S4) brought out signals characteristics of steroidal derivatives. Namely, the ${ }^{1} \mathrm{H}$ NMR (Table 2) and HSQC (Figure S7) spectra allowed to refer signals of five methyl groups as belonging to Me-18 $\left(\delta_{\mathrm{H}} 0.71, \mathrm{~s} ; \delta_{\mathrm{C}} 12.4\right)$, Me-19 $\left(\delta_{\mathrm{H}} 0.92, \mathrm{~s} ; \delta_{\mathrm{C}} 14.9\right), \mathrm{Me}-21\left(\delta_{\mathrm{H}} 0.96, \mathrm{~d}, J=6.5 \mathrm{~Hz} ; \delta_{\mathrm{C}} 18.9\right), \mathrm{Me}-26\left(\delta_{\mathrm{H}} 1.03, \mathrm{~d}, J=6.8 \mathrm{~Hz}\right.$; $\left.\delta_{\mathrm{C}} 22.1\right)$, and Me-27 $\left(\delta_{\mathrm{H}} 1.02, \mathrm{~d}, J=6.8 \mathrm{~Hz} ; \delta_{\mathrm{C}} 22.2\right)$. The chemical shifts at $\delta_{\mathrm{H}} 4.12, \mathrm{~m} ; \delta_{\mathrm{C}} 67.4$, $(\mathrm{HC}-3)$, at $\delta_{\mathrm{H}} 5.57, \mathrm{dd}, J=9.8,2.7 \mathrm{~Hz} ; \delta_{\mathrm{C}} 133.5,(\mathrm{HC}-6)$ and at $\delta_{\mathrm{H}} 5.63, \mathrm{dd}, J=9.8,1.6 \mathrm{~Hz} ; \delta_{\mathrm{C}} 133.4$ (HC-7) along with oxygenated non-protonated carbon signal $\delta_{C} 74.2$ (C-5), suggested the $3 \beta, 5 \alpha-6$-ene steroidal core [13,14]. It was supported by close similarity of the corresponding ${ }^{13} \mathrm{C}$ NMR signals of 1 and known cholest-6-ene- $3 \beta, 5 \alpha$-diol while the epimoric compound with $3 \beta, 5 \beta$-6-ene core was quite different [13]. As the signals at $\delta_{\mathrm{H}} 4.66(\mathrm{~s})$ and 4.72 (s) showed an exo-methylene double bond $\left(\delta_{\mathrm{C}} 106.3\right.$ and 157.1), the 24(28)-ergostene side-chain was deduced for compound 1 . Therefore, the structure of new compound 1 was established as 24-methylcholesta-6,24(28)-diene-3 $\beta, 5 \alpha$-diol.

Table 1. ${ }^{13} \mathrm{C}$ NMR data of Compounds 1-4 ( 8 in ppm, $\left.\mathrm{CDCl}_{3}\right)$.

\begin{tabular}{|c|c|c|c|c|}
\hline No. & $1^{a}$ & $2^{a}$ & $3^{b}$ & $4^{a}$ \\
\hline 1 & 28.5 & 36.7 & 37.0 & 37.0 \\
\hline 2 & 30.8 & 28.1 & 31.4 & 31.6 \\
\hline 3 & 67.4 & 76.6 & 71.4 & 71.5 \\
\hline 4 & 41.2 & 75.2 & 42.1 & 41.8 \\
\hline 5 & 74.2 & 142.1 & 146.2 & 143.7 \\
\hline 6 & 133.5 & 117.8 & 123.9 & 125.5 \\
\hline 7 & 133.4 & 31.6 & 65.3 & 73.4 \\
\hline 8 & 38.7 & 31.5 & 37.5 & 40.9 \\
\hline 9 & 45.3 & 50.5 & 42.3 & 48.3 \\
\hline 10 & 38.3 & 38.1 & 37.4 & 36.5 \\
\hline 11 & 21.3 & 20.9 & 20.7 & 21.1 \\
\hline 12 & 40.3 & 39.8 & 39.1 & 39.5 \\
\hline 13 & 44.0 & 42.3 & 42.0 & 42.8 \\
\hline 14 & 54.2 & 56.8 & 49.5 & 56.0 \\
\hline 15 & 24.1 & 24.3 & 24.2 & 26.3 \\
\hline 16 & 28.8 & 28.2 & 28.4 & 28.6 \\
\hline 17 & 56.1 & 56.0 & 55.8 & 55.4 \\
\hline 18 & 12.4 & 11.9 & 11.9 & 12.1 \\
\hline 19 & 14.9 & 20.2 & 18.2 & 19.2 \\
\hline 20 & 36.0 & 35.8 & 39.8 & 39.7 \\
\hline 21 & 18.9 & 18.7 & 20.8 & 20.9 \\
\hline 22 & 34.9 & 34.7 & 133.6 & 133.5 \\
\hline 23 & 31.3 & 31.0 & 134.9 & 135.0 \\
\hline 24 & 157.1 & 156.9 & & \\
\hline 25 & 34.1 & 33.8 & 30.9 & 30.9 \\
\hline 26 & 22.1 & 21.9 & 22.7 & 22.7 \\
\hline 27 & 22.2 & 22.0 & 22.7 & 22.7 \\
\hline 28 & 106.3 & 106.0 & & \\
\hline
\end{tabular}

Compound 2 has the molecular formula $\mathrm{C}_{28} \mathrm{H}_{46} \mathrm{O}_{2}$ that was determined by (+) HRESI MS m/z $437.3393[\mathrm{M}+\mathrm{Na}]^{+}$and ${ }^{13} \mathrm{C}$ NMR (Figures S2 and S9; Table 1). The NMR data of 2 (Tables 1 and 2; Figures S8-S11) also confirmed its steroidal framework. At first, they showed the same type of side-chain in the structure $\mathbf{2}$ as in $\mathbf{1}$ by the presence of very close chemical shifts in the spectra of both compounds. The remaining signals were attributed to Me-18 $\left(\delta_{\mathrm{H}} 0.69, \mathrm{~s} ; \delta_{\mathrm{C}} 11.9\right), \mathrm{Me}-19\left(\delta_{\mathrm{H}} 1.03, \mathrm{~s} ; \delta_{\mathrm{C}}\right.$ $20.2), 4 \alpha-\mathrm{OH}\left(\delta_{\mathrm{H}} 4.06, \mathrm{~m} ; \delta_{\mathrm{C}} 75.2\right)$, and trisubstituted $5(6)$-double bond $\left(\delta_{\mathrm{H}} 5.74, \mathrm{dt}, J=5.5,2.2 \mathrm{~Hz} ; \delta_{\mathrm{C}}\right.$ 117.8 , HC- 6 and $\left.\delta_{C} 142.2, C-5\right)$ of the previously described $4 \alpha$-hydroxylated tetracyclic system. Really, the both $4 \alpha$-hydroxy- and $4 \beta$-hydroxycholesterols were obtained and well characterized during the investigation of cholesterol autoxidation [15]. As a result of the thorough comparison of $1 \mathrm{D}$ and 2D 
NMR experimental data of 2 with published values, the structure of this new oxysterol was deduced as 24 -methylcholesta-5,24(28)-diene-3 $\beta, 4 \alpha$-diol.

Table 2. ${ }^{1} \mathrm{H}$ NMR data of Compounds 1-4 ( $\delta$ in ppm, $J$ in $\left.\mathrm{Hz}, \mathrm{CDCl}_{3}\right)$.

\begin{tabular}{|c|c|c|c|c|}
\hline No. ${ }^{a}$ & $1^{b}$ & $2^{\mathrm{c}}$ & $3^{c}$ & $4^{b}$ \\
\hline \multirow{2}{*}{1} & $\alpha: 1.62, \mathrm{~m}$ & $\alpha: 1.14, \mathrm{~m}$ & $\alpha: 1.12, \mathrm{~m}$ & $\alpha: 1.06, \mathrm{~m}$ \\
\hline & $\beta: 1.37, \mathrm{~m}$ & $\beta: 1.84, \mathrm{~m}$ & $\beta: 1.87, \mathrm{~m}$ & $\beta: 1.85, \mathrm{~m}$ \\
\hline \multirow{2}{*}{2} & $\alpha: 1.89, \mathrm{~m}$ & $\alpha: 1.89, \mathrm{~m}$ & $\alpha: 1.86, \mathrm{~m}$ & $\alpha: 1.85, \mathrm{~m}$ \\
\hline & $\beta: 1.55, \mathrm{~m}$ & $\beta: 1.60, \mathrm{~m}$ & $\beta: 1.52, \mathrm{~m}$ & $\beta: 1.52, \mathrm{~m}$ \\
\hline 3 & $4.12, \mathrm{~m}$ & $3.27, \operatorname{td}(10.5,4.9)$ & $3.39, \mathrm{~m}$ & $3.55, \mathrm{~m}$ \\
\hline \multirow{2}{*}{4} & $\alpha: 1.80, \mathrm{dd}(12.4,4.9)$ & \multirow{3}{*}{$4.06, \mathrm{~m}$} & $\alpha: 2.34$, ddd $(13.2,4.9,2.2)$ & $\alpha: 2.34, \operatorname{ddd}(13.2,5.2,2.3)$ \\
\hline & $\beta: 1.64, \mathrm{~m}$ & & $\beta: 2.29, \operatorname{ddt}(13.2,11.3,1.8)$ & $\beta: 2.26, \operatorname{ddt}(13.2,11.3,2.2)$ \\
\hline 5 & & & & \\
\hline 6 & $5.57, \mathrm{dd}(9.8,2.7)$ & $5.74, \mathrm{dt}(5.5,2.2)$ & $5.60, \mathrm{dd}(5.3,1.6)$ & 5.29, br t $(2.2)$ \\
\hline 7 & $5.63, \mathrm{dd}(9.8,1.6)$ & $\begin{array}{l}\alpha: 1.58, \mathrm{~m} \\
\beta: 2.10, \mathrm{~m}\end{array}$ & 3.85, br s & $3.84, \mathrm{dt}(8.3,2.2)$ \\
\hline 8 & $1.93, \mathrm{~m}$ & $1.44, \mathrm{~m}$ & $1.47, \mathrm{~m}$ & $1.40, \mathrm{~m}$ \\
\hline 9 & $1.48, \mathrm{dd}(11.6,3.9)$ & $0.99, \mathrm{~m}$ & $1.23, \mathrm{~m}$ & $1.03, \mathrm{~m}$ \\
\hline \multicolumn{5}{|c|}{ 然 } \\
\hline \multirow{2}{*}{11} & $\alpha: 1.44, \mathrm{~m}$ & $\alpha: 1.01, \mathrm{~m}$ & $\alpha: 1.54, \mathrm{~m}$ & $\alpha: 1.53, \mathrm{~m}$ \\
\hline & $\beta: 1.31, \mathrm{~m}$ & $\beta: 1.48, \mathrm{~m}$ & $\beta: 1.49, \mathrm{~m}$ & $\beta: 1.47, \mathrm{~m}$ \\
\hline \multirow{2}{*}{12} & $\alpha: 1.23, \mathrm{~m}$ & $\alpha: 1.18, \operatorname{td}(12.7,5.2)$ & $\alpha: 1.19, \mathrm{~m}$ & $\alpha: 1.15, \mathrm{~m}$ \\
\hline & $\beta: 2.05, \mathrm{dt}(12.5,3.1)$ & $\beta: 2.03, \mathrm{dt}(12.7,3.7)$ & $\beta: 1.98, \mathrm{dt}(12.6,3.5)$ & $\beta: 1.99, \mathrm{~m}$ \\
\hline 13 & & & & \\
\hline 14 & $1.23, \mathrm{~m}$ & $1.00, \mathrm{~m}$ & $1.44, \mathrm{~m}$ & $1.16, \mathrm{~m}$ \\
\hline \multirow{2}{*}{15} & $\alpha: 1.67, \mathrm{~m}$ & $\alpha: 1.61, \mathrm{~m}$ & $\alpha: 1.67, \mathrm{~m}$ & $\alpha: 1.77, \mathrm{~m}$ \\
\hline & $\beta: 1.22, \mathrm{~m}$ & $\beta: 1.10, \mathrm{~m}$ & $\beta: 1.12, \mathrm{~m}$ & $\beta: 1.40, \mathrm{~m}$ \\
\hline \multirow{2}{*}{16} & $\alpha: 1.89, \mathrm{~m}$ & $\alpha: 1.87, \mathrm{~m}$ & $\alpha: 1.73, \mathrm{~m}$ & $\alpha: 1.71, \mathrm{~m}$ \\
\hline & $\beta: 1.32, \mathrm{~m}$ & $\beta: 1.29, \mathrm{~m}$ & $\beta: 1.29, \mathrm{~m}$ & $\beta: 1.30, \mathrm{~m}$ \\
\hline 17 & $1.17, \mathrm{~m}$ & $1.14, \mathrm{~m}$ & $1.20, \mathrm{~m}$ & $1.12, \mathrm{~m}$ \\
\hline 18 & $0.71, \mathrm{~s}$ & $0.69, \mathrm{~s}$ & $0.70, \mathrm{~s}$ & $0.70, \mathrm{~s}$ \\
\hline 19 & $0.92, \mathrm{~s}$ & $1.03, \mathrm{~s}$ & $1.00, \mathrm{~s}$ & $1.35, \mathrm{~s}$ \\
\hline 20 & $1.43, \mathrm{~m}$ & $1.42, \mathrm{~m}$ & $2.01, \mathrm{~m}$ & $2.00, \mathrm{~m}$ \\
\hline 21 & $0.96, \mathrm{~d}(6.5)$ & $0.95, d(6.6)$ & $1.01, \mathrm{~d}(6.7)$ & $1.01, d(6.6)$ \\
\hline 22 & $1.16, \mathrm{~m}$ & $1.16, \mathrm{~m}$ & 5.18, dd $(15.4,8.4)$ & 5.18, dd $(15.4,8.4)$ \\
\hline \multirow{2}{*}{23} & $1.88, \mathrm{~m}$ & $1.88, \mathrm{~m}$ & 527 dd 15366$)$ & $528 \mathrm{dd}(154 \mathrm{65})$ \\
\hline & 2.10, ddd $(15.4,11.5,4.8)$ & $2.09, \mathrm{~m}$ & $5.27, \mathrm{dd}(15.3,6.6)$ & $5.28, \mathrm{dd}(15.4,6.5)$ \\
\hline \multicolumn{5}{|c|}{ - } \\
\hline 25 & 2.23, sept (6.8) & 2.23, sept (7.0) & 2.19, br sept (6.7) & 2.19, br sept $(6.7)$ \\
\hline 26 & $1.03, \mathrm{~d}(6.8)$ & $1.02, \mathrm{~d}(7.0)$ & $0.94, \mathrm{~d}(6.7)$ & $0.95, \mathrm{~d}(6.7)$ \\
\hline 27 & $1.02, \mathrm{~d}(6.8)$ & $1.03, \mathrm{~d}(7.0)$ & $0.94, \mathrm{~d}(6.7)$ & $0.95, \mathrm{~d}(6.7)$ \\
\hline \multirow{2}{*}{28} & $4.66, \mathrm{~s}$ & $4.66, \mathrm{~s}$ & & \\
\hline & $4.72, \mathrm{~s}$ & $4.72, \mathrm{~s}$ & & \\
\hline
\end{tabular}

${ }^{a}$ Assignments were made with the aid of the ${ }^{1} \mathrm{H}^{-1} \mathrm{H}$ COSY and HSQC spectra; ${ }^{\mathrm{b}}$ spectra recorded at $500.13 \mathrm{MHz} ;{ }^{\mathrm{c}}$ spectra recorded at $700.13 \mathrm{MHz}$.

The structure of the compound 3 corresponds to the molecular formula $\mathrm{C}_{26} \mathrm{H}_{42} \mathrm{O}_{2}$ (HRESI MS $m / z 409.3081[\mathrm{M}+\mathrm{Na}]^{+}$) (Figures S2 and S14; Table 1). It has a common $\Delta^{5}-3 \beta, 7 \alpha$-diol steroidal core that has been confirmed by the signals of Me-18 $\left(\delta_{\mathrm{H}} 0.70, \mathrm{~s} ; \delta_{\mathrm{C}} 11.9\right), \mathrm{Me}-19\left(\delta_{\mathrm{H}} 1.00, \mathrm{~s} ; \delta_{\mathrm{C}} 18.2\right)$, two methines, connected with hydroxy groups $\left(\delta_{\mathrm{H}} 3.59, \mathrm{~m} ; \delta_{\mathrm{C}} 71.4, \mathrm{HC}-3\right.$ and $\delta_{\mathrm{H}} 3.85$, br s; $\left.\delta_{\mathrm{C}} 65.3, \mathrm{HC}-7\right)$, and the 5(6)-double bond $\left(\delta_{\mathrm{H}} 5.60, \mathrm{dd}, J=5.3,1.6 \mathrm{~Hz} ; \delta_{\mathrm{C}} 123.9, \mathrm{HC}-6\right.$ and $\left.\delta_{\mathrm{C}} 146.2, \mathrm{C}-5\right)$ [16]. However, the molecular formula and characteristic signals of the $22 E$-double bond $\left(\delta_{\mathrm{H}} 5.18, \mathrm{dd}, J=15.3,6.6 \mathrm{~Hz}\right.$; $\delta_{\mathrm{C}} 133.6, \mathrm{HC}-22$ and $\left.\delta_{\mathrm{H}} 5.27, \mathrm{dd}, J=15.3,6.6 \mathrm{~Hz} ; \delta_{\mathrm{C}} 134.9, \mathrm{HC}-23\right)$, as well as Me-26,27 signals $\left(\delta_{\mathrm{H}}\right.$ $\left.0.94, \mathrm{~d}, J=6.7 \mathrm{~Hz} ; 6 \mathrm{H} ; \delta_{\mathrm{C}} 22.7\right)$ showed that this new steroid was characterized by the presence of the 22E-unsaturated 24-nor-side chain [17] (Tables 1 and 2; Figures S13-S18). Finally, the structure of new oxysterol 3 was determined as (22E)-24-nor-cholesta-5,22-diene-3 $\beta, 7 \alpha$-diol (3) that was also in good agreement with ROESY and HMBC data (Figures S16 and S18).

The $\mathrm{C}_{26} \mathrm{H}_{42} \mathrm{O}_{2}$ molecular formula ((+) HRESI MS $\left.m / z 409.3081[\mathrm{M}+\mathrm{Na}]^{+}\right)$of compound 4 together with similar NMR spectral characteristics (Tables 1 and 2; Figures S2, S19-S24) suggested the presence 
of a side-chain the same as in compound 3. The core parts of these compounds also demonstrated a set of close ${ }^{1} \mathrm{H}$ NMR signals except for the chemical shift values, constants, and multiplicity of $\mathrm{H}-6$ $\left(\delta_{\mathrm{H}} 5.29, \mathrm{t}, J=2.2 \mathrm{~Hz}\right)$ and $\mathrm{H}-7\left(\delta_{\mathrm{H}} 3.85, \mathrm{dt}, J=8.3,2.2 \mathrm{~Hz}\right)$. Both mentioned signals were similar to those described previously $[16,18]$ and suggested the $7 \beta-\mathrm{OH}$ stereochemistry in 4 . All these data along with confirmation by ROESY and HMBC spectra (Figures S22 and S24) allowed to establish the (22E)-24-nor-cholesta-5,22-diene-3 $\beta, 7 \beta$-diol (4) structure of this new oxysterol.

Additionally, the remaining ten isolated compounds 5-14 were identified as known oxygenated steroidal derivatives by spectroscopic methods and comparison with reported data including NMR spectra [16,18-20]. Most of them were described as naturally occurring metabolites possessing diverse biological activities. Thus, (22E)-cholesta-5,22-diene-3 $\beta, 7 \alpha$-diol (5) was originally isolated from the marine sponge Cliona copiosa [16], and demonstrated anti-inflammatory, analgesic and gastroprotective activities as a component of ethanolic fraction of gorgonian Eunicella singularis [21]. The (22E)-cholesta-5,22-diene-3 $\beta, 7 \beta$-diol (6) [16] deterred starfish predators [22]. Selective activity towards DNA repair-deficient yeast mutants and cytotoxicity towards wild-type P-388 murine leukemia cells [23] were showed for 24-methylene-5-cholestene-3 $\beta, 7 \alpha$-diol (7) [18]. Moreover, the compound 7 was noted as a potential drug development candidate for Alzheimer's disease due to inhibitory potential against butyrylcholinesterase (BuChE) with $\mathrm{IC}_{50} 9.5 \mu \mathrm{M}$ [24]. The 24-methylene-5-cholestene-3 $\beta, 7 \beta$-diol (8) [18] was completely inactive in the screening for DNA-damaging agents in the RAD 52 yeast assay (while its epimer 7 was active with $\mathrm{IC}_{50} 7 \mu \mathrm{g} / \mathrm{mL}$ ), and showed moderate cytotoxic activity $\left(\mathrm{IC}_{50} 31 \mu \mathrm{M}\right)$ in the Vero cell assay, indicating that $7 \beta-\mathrm{OH}$ compound acted by a different mechanism in comparison with its $\alpha$-counterpart [25]. Both compounds 7 and $\mathbf{8}$ were also noted as constituents of the royal jelly of honeybees [26].

To the best of our knowledge there are not any reported bioassay results in relation to (22E,24S)-24-methylcholesta-5,22-diene-3 $\beta, 7 \alpha$-diol (9) $[16], \quad(22 E, 24 S)-24-m e t h y l c h o l e s t a-5,22-d i e n e-3 \beta, 7 \beta$-diol $\quad(10) \quad[16,18], \quad$ and (22E,24R)-24-methylcholesta-5,22-diene-3 $\beta, 7 \alpha$-diol (11) [16,19]. 7 $\quad 7 \beta$-Hydroxycholesterol (12) isolated from the Red Sea grass Thalassodendron ciliatum displayed an inhibitory activity against breast carcinoma cell line MCF-7 ( $\mathrm{IC}_{50} 18.6 \pm 0.72 \mu \mathrm{M}$ ) and liver carcinoma cell line Hep G2 ( $\mathrm{IC}_{50}$ $25.4 \pm 0.38 \mu \mathrm{M})$. However, it did not show the anti-inflammatory action on carrageenan-induced rat hind paw edema model [27]. When human THP-1 macrophages were exposed with an atheroma-relevant mixture of $7 \beta$-hydroxycholesterol (12) and 7-ketocholesterol followed by proteome analysis, the alterations in macrophage proteome were indicated with a significant differential expression of 19 proteins [28].

3ß-Hydroxy-24-methylene-5-cholesten-7-one (13) [18] exhibited the potent inhibitory activity on the interleukin-6 production, with $54.0 \%$ inhibition at $10 \mu \mathrm{M}$ and $\mathrm{IC}_{50} 9.4 \pm 1.2 \mu \mathrm{M}$ [29]. 24-Methylenecholest-4-ene-3 $\beta, 6 \beta$-diol (14) [20] demonstrated the cytotoxic activity against the leukemia P-388 cell line with an $\mathrm{IC}_{50} 1 \mu \mathrm{g} / \mathrm{mL}$ [30].

Encouraged with the short literature review presented above, that shows different attractive bioactivities of oxysterols, we have made an attempt to evaluate the action of the isolated compounds 1-14 on viability of Neuro2a cells and reactive oxygen species (ROS) formation in these cells. In fact, neuroblastoma cells treated by 6-hydroxydopamine (6-OHDA) are used as a cell model of PD [31].

Compounds 4, 5, 9 and 12 did not show any notable effects on Neuro2a cell viability. Compounds $1,2,7,8,13$ and 14 demonstrated slight cytotoxic activity at concentration $100 \mu \mathrm{M}$ and decreased viability of Neuro2a cells on $25 \%, 17 \%, 44 \%, 27 \%, 38 \%$ and $33 \%$, respectively. It is of interest that all of them have the same structural peculiarity, being the 24 (28)-unsaturated derivatives of ergostane series. No compounds decreasing cell viability more than $50 \%$ were found. At concentration of $10 \mu \mathrm{M}$, the oxysteroids 1-14 were non-toxic against these neuronal cells, and were used in next experiments at the non-toxic concentrations (Figure S25). Moreover, compounds 3, 6, 10 and 11 increased the viability of Neuro 2a cells in comparison with non-treated cells, when MTT cell viability test was used (Figure 2a and Figure S25). 


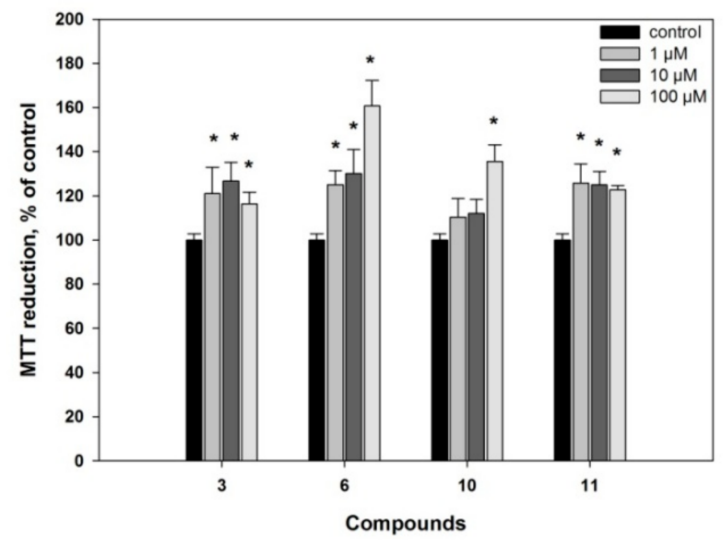

(a)

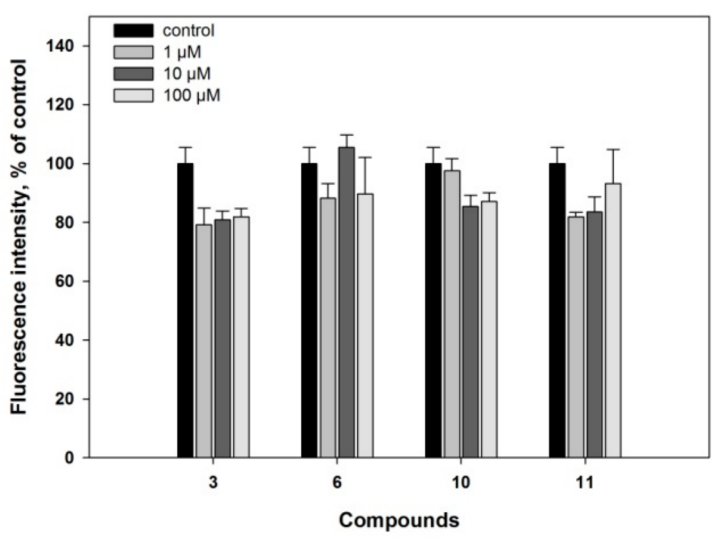

(b)

Figure 2. Compounds 3, 6, 10 and 11: (a) Caused a statistically significant overestimation of MTT reduction in MTT cell viability assay; (b) did not statistically significant affect activity of nonspecific esterase in fluorescein diacetate cell viability test. * Statistically significant differences $(p \leq 0.05)$ between results for control cells and cells incubated with these compounds.

Applied MTT assay is one of the most widely exploited approaches in research for measuring cell proliferation, viability and drug cytotoxicity. In living cells, the water-soluble yellow dye MTT is reduced to a dark purple (blue-magenta) colored formazan precipitate, which can be analyzed colorimetrically after dissolving in an organic solvent. It was shown, that the MTT reduction site is not only mitochondria. Non-mitochondrial, cytosolic and microsomal MTT reduction makes the major contribution to an overall reduction. Changes in the activity of dozens of the mitochondrial and non-mitochondrial oxidoreductases, cellular metabolic and energy perturbations, and oxidative stress may significantly impact the MTT assay read out [32].

To study action of the tested compounds on cells in details, we additionally used fluorescein diacetate (FDA) assay based on nonspecific esterase activity measuring and thus examined the influence of compounds 3, 6, 10 and 11 on proliferation or/and viability of Neuro 2a cells [33]. Compounds 3, 6, 10 and 11 did not increase the fluorescence intensity in FDA assay in comparison with control and therefore did not influence significantly on nonspecific esterase activity in Neuro2a cells (Figure 2b). Hence, we could conclude that the observed increasing of MTT reduction was not caused by the influence of tested compounds on cell proliferation.

In fact, the overestimation in MTT assay of the compounds 3, 6, 10 and $\mathbf{1 1}$ could be caused by alternative metabolic processes. For example, the overestimation reported for rottlerin was explained by dissipation of the inner mitochondrial membrane potential, acceleration of electron transfer and increasing of dehydrogenases activity, oxygen consumption and NADH oxidation [33]. On the other hand the polyphenolic antioxidant resveratrol exhibited increasing of MTT-reducing activity without a corresponding increasing of living cells number [34]. The ability of resveratrol to down-regulate NADPH-oxidase leading to decreased ROS production and thereby provide a protective effect in cardiovascular and neurodegenerative diseases is also well known [35].

As the above reviewed reports described the influence of compounds on intracellular ROS formation, we investigated the effect of compounds 1-14 on ROS formation in Neuro 2a cells by short-time $2^{\prime}, 7^{\prime}$-dichlorodihydrofluorescein diacetate (H2DCF-DA) test. Oxysterols 1-4, 8, 10 and 13 at concentrations of 1 or/and $10 \mu \mathrm{M}$ slightly decreased the ROS level in Neuro2a cells by 12-16\%, while the increasing in ROS formation was not detected for all the studied compounds (Figure S26).

PD is the one of the most common age-related motoric neurodegenerative disease, regardless of countries and regions [36]. Pathogenesis of PD includes neuronal death as a result of oxidative stress involved intracellular level of ROS increasing. In this reason, compounds exhibited ROS-scavenger activities could be interesting as neuroprotective agents. All isolated compounds 1-14 were studied in 
6-OHDA-induced Neuro2a cell model of PD (Figure S26). Only compounds 3, 4 and 11 affected on viability of 6-OHDA-treated cells (Figure 3a) and ROS formation in these cells (Figure 3b).

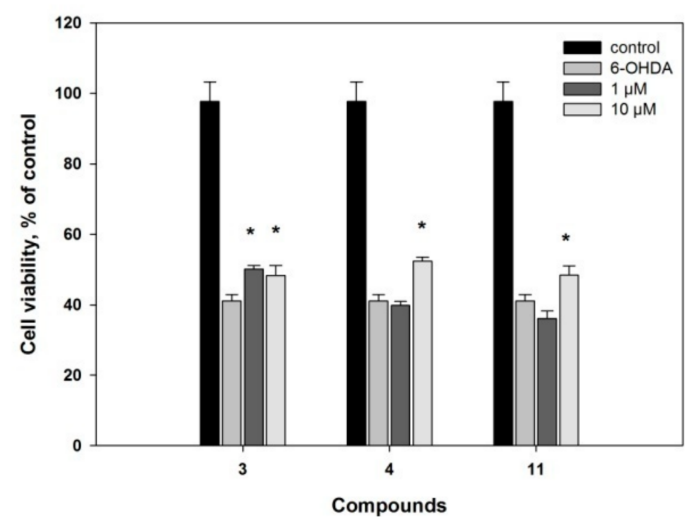

(a)

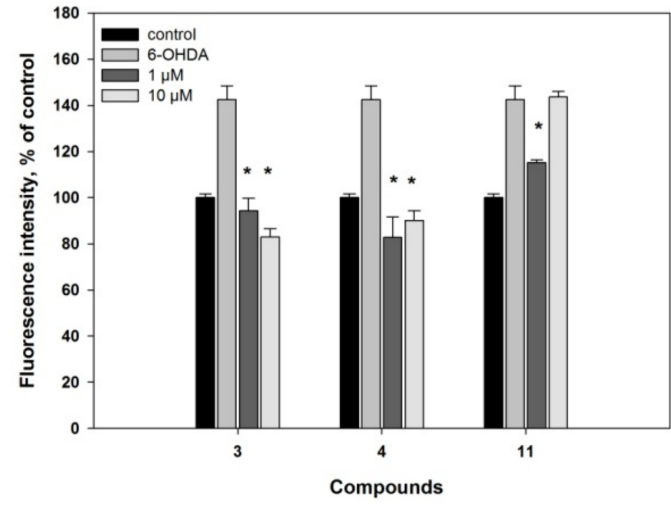

(b)

Figure 3. Influence of compounds 3, 4 and $\mathbf{1 1}$ in 6-OHDA-treated Neuro2a cells: (a) on cell viability; (b) on ROS formation. * Statistically significant differences $(p \leq 0.05)$ between results for 6-OHDA-treated cells and cells incubated with compounds.

As a result, compound 3 increased the viability of 6-OHDA-treated cells by $18 \%$ (at the dose of $10 \mu \mathrm{M})$ and $22 \%(1 \mu \mathrm{M})$, while compounds 4 and 11 increased cell viability by $28 \%(10 \mu \mathrm{M})$ and $18 \%$ $(10 \mu \mathrm{M})$, correspondingly. All these compounds decreased ROS formation in 6-OHDA-treated cells to normal value in similar manner. Thus, compound 4 exhibits the essential neuroprotective activity in 6-OHDA-induced model of Parkinson's disease, probably due to ROS scavenging effect. Oxysterols 3 , 6, 10 and 11 may positively influence on metabolic processes in the Neuro2a cells because they show the overestimation of survival in MTT assay.

\section{Materials and Methods}

\subsection{General Methods}

Optical rotations were measured on a Perkin-Elmer 343 digital polarimeter (Perkin Elmer, Waltham, MA, USA). The ${ }^{1} \mathrm{H}$ and ${ }^{13} \mathrm{C}$ NMR spectra were recorded in $\mathrm{CDCl}_{3}$ using Bruker Avance III 500 (Bruker BioSpin GmbH, Rheinstetten, Germany) (500.13/125.77 MHz) or Avance III 700 Bruker FT-NMR (Bruker BioSpin GmbH, Rheinstetten, Germany) (700.13/176.04 MHz) spectrometers. HRESI and ESI mass spectra were recorded on an Agilent 6510 Q-TOF LC/MS mass spectrometer (Agilent Technologies, Santa Clara, CA, USA), and samples were dissolved in methanol (c $0.01 \mathrm{mg} / \mathrm{mL})$. TLC was carried out on silica gel plates (CTX-1A, 5-17 $\mu \mathrm{m}$, Sorbfil, Russia) and spots were visualized by spraying with aqueous $10 \% \mathrm{H}_{2} \mathrm{SO}_{4}$ followed by heating. Column chromatography (CC) was performed on silica gel (KSK, 50-160 mesh, Sorbfil, Russia) and YMC ODS-A (12 nm, S-75 um, YMC Co., Ishikawa, Japan). HPLC was performed using an Agilent 1100 Series chromatograph with a differential refractometer (Agilent Technologies, Santa Clara, CA, USA). The reversed-phase columns (YMC-Pack ODS-A, YMC Co., Ishikawa, Japan, $10 \mathrm{~mm} \times 250 \mathrm{~mm}, 5 \mu \mathrm{m}$ and $4.6 \mathrm{~mm} \times 250 \mathrm{~mm}$, $5 \mu \mathrm{m})$ and normal-phase column (Ultrashere-Si, Beckman Instruments, Inc., Berkeley, CA, USA, $10 \mathrm{~mm} \times 250 \mathrm{~mm}, 5 \mu \mathrm{m}$ ) were used for HPLC. Yields are based on dry weight of the sponge.

\subsection{Animal Material}

The samples of an Inflatella sp. sponge were collected by dredging near Kashevarov Bank, the Sea of Okhotsk ( $55^{\circ} 30^{\prime} \mathrm{N} ; 146^{\circ} 05^{\prime} \mathrm{E}$, Russia) at a depth of 214-197 $\mathrm{m}$ and were freeze dried after collection. The species was identified by Dr. Krasokhin V. B. from G.B. Elyakov Pacific Institute of Bioorganic 
Chemistry, FEB RAS. A voucher specimen (PIBOC O07-33(11)) is deposited at the G.B. Elyakov Pacific Institute of Bioorganic Chemistry, FEB RAS (Vladivostok, Russia).

\subsection{Extraction and Isolation}

The sponge material (dry weight $216 \mathrm{~g}$ ) was chopped into pieces and extracted with EtOH at room temperature. The ethanol soluble materials $(21.0 \mathrm{~g})$ were obtained after concentration of the extract was dissolved in distilled water $(300 \mathrm{~mL})$ and partitioned in turn with $\mathrm{CHCl}_{3}(200 \mathrm{~mL} \times 3)$. Evaporation of the chloroform extracts gave dark green gum $(12.7 \mathrm{~g})$ that was further separated on a silica gel column $(7 \mathrm{~cm} \times 10 \mathrm{~cm})$ using the mixtures of $\mathrm{CHCl}_{3} / \mathrm{EtOH}$ as stepwise eluent systems to yield the fractions A-F (Figure S1).

Fraction $\mathrm{D}(301.4 \mathrm{mg})$, eluted with $\mathrm{CHCl}_{3} / \mathrm{EtOH}(15: 1)$, was separated by column chromatography (CC) (YMC ODS-A, $15 \mathrm{~mm} \times 100 \mathrm{~mm}, \mathrm{MeOH} / \mathrm{H}_{2} \mathrm{O}, 90-100 \%$ ) to yield three subfractions (D1-D3). The subfraction D1 (128.5 mg) was further subjected to silica gel CC (hexane/EtOAc stepwise systems) to obtain three subfractions. The subfraction D1.2 $(17.0 \mathrm{mg})$ was purified by normal-phase HPLC (Ultrasphere-Si, hexane/EtOAc, 1:1, $2 \mathrm{~mL} / \mathrm{min}$ ) to yield compound 13 (6.3 mg, 0.003\%). Subfraction D1.3 (6.6 mg) was separated by reverse-phase HPLC (YMC-Pack ODS-A, $10 \mathrm{~mm} \times 250 \mathrm{~mm}, 95 \%$ $\mathrm{MeOH}, 2 \mathrm{~mL} / \mathrm{min})$ to obtain compounds $\mathbf{1}(0.8 \mathrm{mg}, 0.0004 \%), 3(0.4 \mathrm{mg}, 0.003 \%)$ and $7(1.8 \mathrm{mg}, 0.012 \%)$.

Fraction $\mathrm{E}(904.4 \mathrm{mg})$, eluted with $\mathrm{CHCl}_{3} / \mathrm{EtOH}$ (10:1), was fractionated by silica gel CC $(25 \mathrm{~mm} \times 60 \mathrm{~mm}$, hexane/EtOAc, 1:1) to yield four smaller fractions. Fraction E2 (227.4 mg) was subjected to normal-phase HPLC (Ultrasphere-Si, hexane/EtOAc, 1:1, $2 \mathrm{~mL} / \mathrm{min}$ ) resulting in three subfractions. The first subfraction E2.1 $(4.0 \mathrm{mg})$ was purified using reverse-phase HPLC (YMC-Pack ODS-A, $4.6 \mathrm{~mm} \times 250 \mathrm{~mm}, 90 \% \mathrm{EtOH}, 0.6 \mathrm{~mL} / \mathrm{min})$ to afford compound $2(0.8 \mathrm{mg}, 0.0004 \%)$ and to re-isolate metabolite $13(1.1 \mathrm{mg})$. As a result of the process of E2.2 $(22.9 \mathrm{mg})$ reverse-phase separation (YMC-Pack ODS-A, $10 \mathrm{~mm} \times 250 \mathrm{~mm}, 2 \mathrm{~mL} / \mathrm{min}$ ) in $95 \% \mathrm{MeOH}$, the compounds $4(1.0 \mathrm{mg}, 0.0005 \%)$, $\mathbf{6}(2.4 \mathrm{mg}, 0.001 \%), \mathbf{8}(6.3 \mathrm{mg}, 0.003 \%), \mathbf{1 0}(2.0 \mathrm{mg}, 0.0009 \%)$ and $\mathbf{1 2}(1.7 \mathrm{mg}, 0.0008 \%)$ were obtained. The last mentioned HPLC procedures and $94 \% \mathrm{MeOH}$ as eluent were used for the subfraction E2.3 that allowed us to isolate the individual steroids 5 (6.8 $\mathrm{mg}, 0.003 \%), \mathbf{9}(3.3 \mathrm{mg}, 0.002 \%), \mathbf{1 1}(8.0 \mathrm{mg}$, $0.004 \%), \mathbf{1 4}(1.3 \mathrm{mg}, 0.0006 \%)$ and to gain new portions of the metabolites $3(5.8 \mathrm{mg})$ and $7(24.3 \mathrm{mg})$.

\subsubsection{4-Methylcholesta-6,24(28)-diene-3 $\beta, 5 \alpha$-diol (1)}

White amorphous powder; $[\alpha]_{\mathrm{D}}^{22}+45.0\left(\mathrm{c} 0.02, \mathrm{CHCl}_{3}\right) ;{ }^{1} \mathrm{H}$ and ${ }^{13} \mathrm{C} \mathrm{NMR}$ data $\left(\mathrm{CDCl}_{3}\right)$, see Tables 1 and 2; EIMS m/z: $414[\mathrm{M}]^{+}(10), 396\left[\mathrm{M}-\mathrm{H}_{2} \mathrm{O}\right]^{+}(100), 378$ (15), 363 (20), 312 (8), 276 (8), 141 (12), 109 (14); (+) HRESI MS m/z $437.3393[\mathrm{M}+\mathrm{Na}]^{+}$(calcd. for $\mathrm{C}_{28} \mathrm{H}_{46} \mathrm{O}_{2} \mathrm{Na}, 437.3390$ ).

\subsubsection{4-Methylcholesta-5,24(28)-diene-3 $\beta, 4 \alpha$-diol (2)}

White amorphous powder; $[\alpha]_{\mathrm{D}}^{22}+50.0\left(c 0.08, \mathrm{CHCl}_{3}\right) ;{ }^{1} \mathrm{H}$ and ${ }^{13} \mathrm{C}$ NMR data $\left(\mathrm{CDCl}_{3}\right)$, see Tables 1 and 2; (+) HRESI MS m/z $437.3393[\mathrm{M}+\mathrm{Na}]^{+}$(calcd. for $\mathrm{C}_{28} \mathrm{H}_{46} \mathrm{O}_{2} \mathrm{Na}, 437.3390$ ).

\subsection{3. (22E)-24-Nor-cholesta-5,22-diene-3 $\beta, 7 \alpha$-diol (3)}

White amorphous powder; $[\alpha]_{\mathrm{D}}^{22}-47.5\left(c\right.$ 0.04, $\left.\mathrm{CHCl}_{3}\right) ;{ }^{1} \mathrm{H}$ and ${ }^{13} \mathrm{C} \mathrm{NMR}$ data $\left(\mathrm{CDCl}_{3}\right)$, see Tables 1 and 2; (+) HRESI MS m/z $409.3081[\mathrm{M}+\mathrm{Na}]^{+}$(calcd. for $\mathrm{C}_{26} \mathrm{H}_{42} \mathrm{O}_{2} \mathrm{Na}$, 409.3077).

\subsection{4. (22E)-24-Nor-cholesta-5,22-diene-3 $\beta, 7 \beta$-diol (4)}

White amorphous powder; $[\alpha]_{\mathrm{D}}^{22}-9.0\left(c 0.10, \mathrm{CHCl}_{3}\right) ;{ }^{1} \mathrm{H}$ and ${ }^{13} \mathrm{C}$ NMR data $\left(\mathrm{CDCl}_{3}\right)$, see Tables 1 and 2; (+) HRESI MS m/z 409.3081 [M + Na] ${ }^{+}$(calcd. for $\mathrm{C}_{26} \mathrm{H}_{42} \mathrm{O}_{2} \mathrm{Na}$, 409.3077). 


\subsection{Biological Activities}

\subsubsection{Cell Line and Culture Condition}

The neuroblastoma cell line Neuro2a was purchased from ATCC. Cells were cultured according to the manufacturer instructions in DMEM medium containing 10\% fetal bovine serum (Biolot, Russia) and $1 \%$ penicillin/streptomycin (Invitrogen). Cells were incubated at $37^{\circ} \mathrm{C}$ in a humidified atmosphere containing $5 \%(v / v) \mathrm{CO}_{2}$.

\subsubsection{MTT Assay}

Cell suspension $\left(1 \times 10^{3}\right.$ cells/well $)$ was incubated with different concentration of compounds during $24 \mathrm{~h}$. After that, cell viability was determined by MTT (3-(4,5-dimethylthiazol-2-yl)-2,5diphenyltetrazolium bromide) method as manufacturer described (Sigma-Aldrich, St. Louis, MO, USA).

\subsubsection{Nonspecific Esterase Activity Assay}

Cell suspension $\left(1 \times 10^{3}\right.$ cells/well $)$ was incubated with different concentrations of the studied compounds during $24 \mathrm{~h}$. A stock solution of the fluorescein diacetate (FDA) (Sigma-Aldrich, USA) in DMSO $(1 \mathrm{mg} / \mathrm{mL})$ was prepared. After incubation of the cells with compounds, FDA solution $(50 \mu \mathrm{g} / \mathrm{mL})$ was added to each well and the plate was incubated at $37^{\circ} \mathrm{C}$ for $15 \mathrm{~min}$. Cells were washed with phosphate buffer saline and fluorescence was measured with a Fluoroskan Ascent plate reader (ThermoLabsystems, Finland) at $\lambda_{\mathrm{ex}}=485 \mathrm{~nm}$ and $\lambda_{\mathrm{em}}=518 \mathrm{~nm}$. Cell viability was expressed as the percent of control.

\subsubsection{6-OHDA-Induced In Vitro Model of Parkinson's Disease}

The neuroprotective activity of the studied compounds in 6-hydroxydopamine-induced cell model of Parkinson's disease was investigated as described previously [37]. Neuroblastoma Neuro2a line cells $\left(1 \times 10^{3}\right.$ cells / well) were treated with compounds at concentrations of 1 and $10 \mu \mathrm{M}$ during $1 \mathrm{~h}$, after that 6-OHDA (Sigma-Aldrich, USA) at concentration of $50 \mu \mathrm{M}$ was added in each well and neuroblastoma cells were cultivated during $24 \mathrm{~h}$. After that, viability of cells was measured by MTT assay. The results were presented as percent of control data.

\subsubsection{Reactive Oxygen Species (ROS) Level Analysis}

Cell suspensions $\left(1 \times 10^{3}\right.$ cells/well) were incubated during $1 \mathrm{~h}$ with 1 and $10 \mu \mathrm{M}$ solutions of the tested compounds. Non-treated and treated with 6-OHDA at concentration of $50 \mu \mathrm{M}$ (Sigma-Aldrich, USA) cells were used as negative and positive controls, respectively. The portion $(20 \mu \mathrm{L})$ of $2^{\prime}, 7^{\prime}$-dichlorodihydrofluorescein diacetate (H2DCF-DA) stock solution (Molecular Probes, Eugene, OR, USA) with concentration of $100 \mathrm{mM}$ was added in each well and the microplate was incubated for an additional $10 \mathrm{~min}$ at $37^{\circ} \mathrm{C}$. The intensity of dichlorofluorescin fluorescence was measured at $\lambda_{\mathrm{ex}}=485 \mathrm{~nm}$, and $\lambda_{\mathrm{em}}=518 \mathrm{~nm}$ with plate reader PHERAstar FS (BMG Labtech, Ortenberg, Germany). The data were processed by MARS Data Analysis v. 3.01R2 (BMG Labtech, Ortenberg, Germany). In other experiments, cells were incubated with compounds during $1 \mathrm{~h}$. Then, 6-OHDA (50 $\mu \mathrm{M})$ was added in each well for $30 \mathrm{~min}$ and ROS levels were measured. All obtained results were presented as percent of negative control data.

\section{Conclusions}

A sponge Inflatella sp. contains a variety of oxysterols differing from each other in positions of additional hydroxy or oxo groups of their tetracyclic core and in structures of side chains. Fourteen oxidized sterols, including four previously unknown compounds, were isolated. Structures of new oxysterols have been established. Previously known compounds were structurally identified by comparison of their NMR and MS spectra with those reported in literature. All of the obtained 
compounds were studied in the 6-hydroxydopamine-induced cell model of Parkinson's disease. At least, one new oxysterol, (22E)-24-nor-cholesta-5,22-diene-3 $\beta, 7 \beta$-diol (4), showed a substantial activity in this test and might be used for the further studies as a drug candidate.

Supplementary Materials: ${ }^{1} \mathrm{H}$ and ${ }^{13} \mathrm{C}$ spectra of new compounds 1-4 are available online at http:/ /www.mdpi. com/1660-3397/16/11/458/s1, Figure S1: Experimental Section, Figure S2: HRESI MS Spectra (Positive Ion Mode) of compounds 1-4 in $\mathrm{CDCl}_{3}$, Figure S3: ${ }^{1} \mathrm{H}$ NMR (500.13 MHz) spectrum of $\mathbf{1}$ in $\mathrm{CDCl}_{3}$, Figure S4: ${ }^{13} \mathrm{C}$ NMR (125.76 MHz) spectrum of $\mathbf{1}$ in CDCl 3 , Figure S5: COSY NMR (700.13 MHz) spectrum of $\mathbf{1}$ in $\mathrm{CDCl}_{3}$, Figure S6: ROESY NMR ( $500.13 \mathrm{MHz}$ ) spectrum of $\mathbf{1}$ in $\mathrm{CDCl}_{3}$, Figure S7: HSQC NMR (700.13 MHz) spectrum of $\mathbf{1}$ in $\mathrm{CDCl}_{3}$, Figure S8: ${ }^{1} \mathrm{H}$ NMR $(700.13 \mathrm{MHz})$ spectrum of 2 in $\mathrm{CDCl}_{3}$, Figure S9: ${ }^{13} \mathrm{C}$ NMR $(125.76 \mathrm{MHz})$ spectrum of 2 in $\mathrm{CDCl}_{3}$, Figure S10: COSY NMR (700.13 MHz) spectrum of 2 in $\mathrm{CDCl}_{3}$, Figure S11: ROESY NMR (700.13 $\mathrm{MHz})$ spectrum of 2 in $\mathrm{CDCl}_{3}$, Figure S12: HSQC NMR (700.13 MHz) spectrum of 2 in $\mathrm{CDCl}_{3}$, Figure S13: ${ }^{1} \mathrm{H}$ NMR (700.13 MHz) spectrum of 3 in $\mathrm{CDCl}_{3}$, Figure S14: ${ }^{13} \mathrm{C} \mathrm{NMR} \mathrm{(176.04} \mathrm{MHz)} \mathrm{spectrum} \mathrm{of} 3$ in $\mathrm{CDCl}_{3}$, Figure S15: COSY NMR (700.13 MHz) spectrum of 3 in $\mathrm{CDCl}_{3}$, Figure S16: ROESY NMR (700.13 MHz) spectrum of 3 in $\mathrm{CDCl}_{3}$, Figure S17: HSQC NMR (700.13 MHz) spectrum of 3 in $\mathrm{CDCl}_{3}$, Figure S18: HMBC NMR (700.13 MHz) spectrum of 3 in $\mathrm{CDCl}_{3}$, Figure S19: ${ }^{1} \mathrm{H}$ NMR $(500.13 \mathrm{MHz})$ spectrum of 4 in $\mathrm{CDCl}_{3}$, Figure S20: ${ }^{13} \mathrm{C}$ NMR (125.76 $\mathrm{MHz}$ ) spectrum of 4 in $\mathrm{CDCl}_{3}$, Figure S21: COSY NMR (500.13 MHz) spectrum of 4 in $\mathrm{CDCl}_{3}$, Figure S22: ROESY NMR (500.13 MHz) spectrum of 4 in $\mathrm{CDCl}_{3}$, Figure S23: HSQC NMR (500.13 MHz) spectrum of 4 in $\mathrm{CDCl}_{3}$, S24: HSQC NMR (500.13 MHz) spectrum of 4 in $\mathrm{CDCl}_{3}$, Figure S25: Viability of Neuro2a cells, Figure S26 ROS formation in Neuro2a cells, Figure S27: Viability of Neuro2a cells treated with 6-OHDA.

Author Contributions: Conceptualization, S.A.K., E.G.L.; methodology, S.A.K., E.G.L.; formal analysis, S.A.K., E.G.L.; investigation, S.A.K., E.G.L. and E.A.Y.; data curation S.A.K., E.G.L.; writing-original draft preparation, S.A.K., E.G.L.; writing - review and editing, S.A.K., E.G.L. and V.A.S; visualization, S.A.K., E.G.L.; bioassay, E.A.Y; NMR data providing, A.I.K.; HRESI MS and EIMS spectra providing, R.S.P.; supervision, V.A.S.; project administration, V.A.S.; funding acquisition, V.A.S.

Funding: This work was supported by the Grant No. 17-14-01065 from the RSF (Russian Science Foundation).

Acknowledgments: The study was carried out on the equipment of the Collective Facilities Center, The Far Eastern Center for Structural Molecular Research (NMR/MS) of PIBOC FEB RAS.

Conflicts of Interest: The authors declare no conflict of interest.

\section{References}

1. Schroepfer, G.J., Jr. Oxysterols: Modulators of cholesterol metabolism and other processes. Physiol. Revs. 2000, 80, 361-554. [CrossRef] [PubMed]

2. Doria, M.; Maugest, L.; Moreau, T.; Lizard, G.; Vejux, A. Contribution of cholesterol and oxysterols to the pathophysiology of Parkinson's disease. Free Radic. Biol. Med. 2016, 101, 393-400. [CrossRef] [PubMed]

3. Griffiths, W.J.; Abdel-Khalik, J.T.; Yutuc, H.E.; Morgan, A.H.; Wang, Y. Current trends in oxysterol research. Biochem. Soc. Trans. 2016, 44, 652-658. [CrossRef] [PubMed]

4. Lee, C.Y.J; Seet, R.C.S.; Huang, S.H.; Long, L.H.; Halliwell, B. Different patterns of oxidized lipid products in plasma and urine of dengue fever, stroke, and Parkinson's disease patients: Cautions in the use of biomarkers of oxidative stress. Antioxyd. Redox Signal. 2009, 11, 407-420. [CrossRef] [PubMed]

5. Marwarha, G.; Rhen, T.; Schommer, T.; Ghribi, O. The oxysterol 27-hydroxycholesterol regulates $\alpha$-synuclein and tyrosine hydroxylase expression levels in human neuroblastoma cells through modulation of liver X receptors and estrogen receptors-relevance to Parkinson's disease. J. Neurochem. 2011, 119, 1119-1136. [CrossRef] [PubMed]

6. Iuliano, L.; Crick, P.J.; Zerbinati, C.; Tritapepe, L.; Abdel-Khalik, J.; Poirot, M.; Wang, Y.; Griffiths, W.J. Cholesterol metabolites exported from human brain. Steroids 2015, 99, 89-93. [CrossRef] [PubMed]

7. Crick, P.J.; Bentley, T.W.; Abdel-Khalik, J.; Matthews, I.; Clayton, P.T.; Morris, A.A.; Bigger, B.W.; Zerbinati, C.; Tritapepe, L.; Iuliano, L.; et al. Quantitative charge-tags for sterol and oxysterol analysis. Clin. Chem. 2015, 61, 400-411. [CrossRef] [PubMed]

8. Zhu, Y.Z.; Liu, J.W.; Wang, X.; Jeong, I.H.; Ahn, Y.J.; Zhang, C.J. Anti-BACE1 and antimicrobial activities of steroidal compounds isolated from marine Urechis unicinctus. Mar. Drugs 2018, 16, 94. [CrossRef] [PubMed]

9. Kolesnikova, S.A.; Lyakhova, E.G.; Kalinovsky, A.I.; Pushilin, M.A.; Afiyatullov, S.S.; Yurchenko, E.A.; Dyshlovoy, S.A.; Minh, C.V.; Stonik, V.A. Isolation, structures, and biological activities of triterpenoids from a Penares sp. marine sponge. J. Nat. Prod. 2013, 76, 1746-1752. [CrossRef] [PubMed] 
10. Lyakhova, E.G.; Kolesnikova, S.A.; Kalinovskii, A.I.; Kim, N.Y.; Krasokhin, V.B.; Stonik, V.A. Secondary metabolites of the marine sponge Penares $c f$. schulzei, fluorescence properties of 24-methylenecholesta-4,6,8(14)-trien-3-one. Chem. Nat. Comp. 2015, 51, 334-335. [CrossRef]

11. Lyakhova, E.G.; Kolesnikova, S.A.; Kalinovsky, A.I.; Dmitrenok, P.S.; Nam, N.H.; Stonik, V.A. Further study on Penares sp. from Vietnamese waters: minor lanostane and nor-lanostane triterpenes. Steroids 2015, 96, 37-43. [CrossRef] [PubMed]

12. Berne, S.; Kalauz, M.; Lapat, M.; Savin, L.; Janussen, D.; Kersken, D.; Avguštin, J.A.; Jokhadar, Š.Z.; Jaklič, D.; Gunde-Cimerman, N.; et al. Screening of the Antarctic marine sponges (Porifera) as a source of bioactive compounds. Polar Biol. 2016, 39, 947-959. [CrossRef]

13. Holland, H.L.; Jahangir. Reactions of steroidal 4,5- and 5,6- epoxides with strong bases. Can. J. Chem. 1983, 61, 2165-2170. [CrossRef]

14. Della Greca, M.; Fiorentino, A.; Molinaro, A.; Monaco, P.; Previtera, L. Hydroperoxysterols in Arum italicum. Nat. Prod. Lett. 1994, 5, 7-14. [CrossRef]

15. Zielinski, Z.A.M.; Pratt, D.A. Cholesterol autoxidation revisited: debunking the dogma associated with the most vilified of lipids. J. Am. Chem. Soc. 2016, 138, 6932-6935. [CrossRef] [PubMed]

16. Notaro, G.; Piccialli, V.; Sica, D. New steroidal hydroxyketones and closely related diols from the marine sponge Cliona copiosa. J. Nat. Prod. 1992, 55, 1588-1594. [CrossRef]

17. Liu, T.F.; Lu, X.; Tang, H.; Zhang, M.M.; Wang, P.; Sun, P.; Liu, Z.Y.; Wang, Z.L.; Li, L.; Rui, Y.C.; et al. $3 \beta, 5 \alpha, 6 \beta$-Oxygenated sterols from the South China Sea gorgonian Muriceopsis flavida and their tumor cell growth inhibitory activity and apoptosis-inducing function. Steroids 2013, 78, 108-114. [CrossRef] [PubMed]

18. Findlay, J.A.; Patil, A.D. Novel sterols from the finger sponge Haliclona oculata. Can. J. Chem. 1985, 63, 2406-2410. [CrossRef]

19. Yang, F.; Zhang, H.-J.; Liu, X.-F.; Chen, W.-S.; Tang, H.-F.; Lin, H.-W. Oxygenated steroids from marine bryozoan Biflustra grandicella. Biochem. System. Ecol. 2009, 37, 686-689. [CrossRef]

20. Anjaneyulu, V.; Babu, B.H.; Rao, K.M.C.A.; Rao, K.N. 24-Methylenecholest-4-ene-3 $\beta$,6 $\beta$-diol from a soft coral Sinularia ovispiculata of the Andaman and Nicobar Islands. Ind. J. Chem. B 1994, 33B, 806-808.

21. Deghrigue, M.; Festa, C.; Ghribi, L.; D’Auria, M.V.; De Marino, S.; Ben Jannet, H.; Bouraoui, A. Anti-inflammatory and analgesic activities with gastroprotective effect of semi-purified fractions and isolation of pure compounds from Mediterranean gorgonian Eunicella singularis. Asian Pac. J. Trop. Med. 2015, 8, 606-611. [CrossRef] [PubMed]

22. Slattery, M.; Hamann, M.T.; McClintock, J.B.; Perry, T.L.; Puglisi, M.P.; Yoshida, W.Y. Ecological role of water-borne metabolites from Antarctic soft corals. Mar. Ecol. Prog. Ser. 1997, 161, 133-144. [CrossRef]

23. Gunatilaka, A.A.L.; Samaranayake, G.; Kingston, D.G.I.; Hoffmann, G.; Johnson, R.K. Bioactive ergost-5-ene-3 $\beta, 7 \alpha$-diol derivatives from Pseudobersama mossambicensis. J. Nat. Prod. 1992, 55, 1648-1654. [CrossRef] [PubMed]

24. Lu, W.; Zhang, C.; Zheng, K.; Su, J.; Zeng, L. Spectral characteristics and cholinesterase inhibitory activities of some $\Delta 5-3 \beta, 7 \beta$-dihydroxy sterols and their C-7 epimers. Tianran Chanwu Yanjiu Yu Kaifa 2006, 18, 893-895.

25. Heltzel, C.E.; Gunatilaka, A.A.L.; Kingston, D.G.I.; Hofmann, G.A.; Johnson, R.K. Synthesis and structure-activity relationships of cytotoxic 7-hydroxy sterols. J. Nat. Prod. 1994, 57, 620-628. [CrossRef] [PubMed]

26. Kodai, T.; Umebayashi, K.; Nakatani, T.; Ishiyama, K.; Noda, N. Compositions of royal jelly II. Organic acid glycosides and sterols of the royal jelly of honeybees (Apis mellifera). Chem. Pharm. Bull. 2007, 55, 1528-1531. [CrossRef] [PubMed]

27. Abdelhameed, R.F.; Ibrahim, A.K.; Yamada, K.; Ahmed, S.A. Cytotoxic and anti-inflammatory compounds from Red Sea grass Thalassodendron ciliatum. Med. Chem. Res. 2018, 27, 1238-1244. [CrossRef]

28. Ward, L.J.; Ljunggren, S.A.; Karlsson, H.; Li, W.; Yuan, X.M. Exposure to atheroma-relevant 7-oxysterols causes proteomic alterations in cell death, cellular longevity, and lipid metabolism in THP-1 macrophages. PLoS ONE 2017, 12, e0174475/1-e0174475/17. [CrossRef] [PubMed]

29. Thao, N.P.; Nam, N.H.; Cuong, N.X.; Tai, B.H.; Quang, T.H.; Ngan, N.T.T.; Luyen, B.T.T.; Yang, S.Y.; Choi, C.H.; Kim, S.; et al. Steroidal constituents from the soft coral Sinularia dissecta and their inhibitory effects on lipopolysaccharide-stimulated production of pro-inflammatory cytokines in bone marrow-derived dendritic cells. Bull. Kor. Chem. Soc. 2013, 34, 949-952. 
30. Zeng, L.; Li, X.; Su, J.; Fu, X.; Schmitz, F.J. A new cytotoxic dihydroxy sterol from the soft coral Alcyonium patagonicum. J. Nat.Prod. 1995, 58, 296-298. [CrossRef] [PubMed]

31. Pasban-Aliabadi, H.; Esmaeili-Mahani, S.; Abbasnejad, M. Orexin-A protects human neuroblastoma SH-SY5Y cells against 6-hydroxydopamine-induced neurotoxicity: involvement of PKC and PI3K signaling pathways. Rejuvenation Res. 2017, 20, 125-133. [CrossRef] [PubMed]

32. Stockert, J.C.; Horobin, R.W.; Colombo, L.L.; Blázquez-Castro, A. Tetrazolium salts and formazan products in cell biology: Viability assessment, fluorescence imaging, and labeling perspectives. Acta Histochem. 2018, 120, 159-167. [CrossRef] [PubMed]

33. Stepanenko, A.A.; Dmitrenko, V.V. Pitfalls of the MTT assay: Direct and off-target effects of inhibitors can result in over/under estimation of cell viability. Gene 2015, 574, 193-203. [CrossRef] [PubMed]

34. Bernhard, D.; Schwaiger, W.; Crazzolara, R.; Tinhofer, I.; Kofler, R.; Csordas, A. Enhanced MTT-reducing activity under growth inhibition by resveratrol in CEM-C7H2 lymphocytic leukemia cells. Cancer Lett. 2003, 195, 193-199. [CrossRef]

35. Bitterman, J.L.; Chung, J.H. Metabolic effects of resveratrol: Addressing the controversies. Cell. Mol. Life Sci. 2015, 72, 1473-1488. [CrossRef] [PubMed]

36. Mhyre, T.R.; Boyd, J.T.; Hamill, R.W.; Maguire-Zeiss, K.A. Parkinson's Disease. Subcell. Biochem. 2012, 65, 389-455. [PubMed]

37. Pan, Z.; Niu, Y.; Liang, Y.; Zhang, X.; Dong, M. $\beta$-Ecdysterone protects SH-SY5Y cells against 6-hydroxydopamine-induced apoptosis via mitochondria-dependent mechanism: Involvement of p38(MAPK)-p53 signaling pathway. Neurotox. Res. 2016, 30, 453-466. [CrossRef] [PubMed]

(C) 2018 by the authors. Licensee MDPI, Basel, Switzerland. This article is an open access article distributed under the terms and conditions of the Creative Commons Attribution (CC BY) license (http:/ / creativecommons.org/licenses/by/4.0/). 